\author{
Sh.S. Rakhmetova* \\ Kokshetau University named after Sh. Ualikhanov \\ (E-mail:Rakhmetova_Shnar@mail.ru)
}

\title{
Modern approaches to teaching a foreign language
}

\begin{abstract}
Modern approaches to teaching a foreign language are considered in the article. Knowledge of one or several foreign languages has become an urgent problem for many people. And in such circumstances, the search for effective approaches to teaching foreign languages aimed at solving specific professional problems has become relevant. The aim of the article is to analyze and classify modern approaches to teaching a foreign language. The above aim allows formulating the objectives of the study is to study the theoretical and methodological base of these approaches; summarize the scientific data on this issue in the article. To solve the set tasks, the paper describes the structures of higher education, the need to modernize the higher education system by the principles of the Bologna Declaration. Researches on educational technology use for teaching and learning in high school are studied. A review of modern sources in the implementation of the reform of the educational standard focused on competency and competency-based approach to teaching a foreign language is carried out. It also analyzes the main theses of the methodology of teaching a foreign language, in particular topical approaches.
\end{abstract}

Keywords: modern approaches, foreign language, education system, training, teaching methods, higher education, educational process, structure.

\section{Introduction}

Nowadays a new education system is being developed in Kazakhstan. It is focused on entering the world's educational space. This process is accompanied by significant changes in the pedagogical theory and practice of the educational process [1].

In a changing educational paradigm, the role of language education is constantly growing. Since a foreign language is considered a tool that allows a person not only to accustom to the modern world but also to fulfill his/her professional duties. Also, it allows him/her the opportunity to expand his/her professional and cultural outlook while studying various sources of information. Knowledge of one or several foreign languages has become an urgent problem for many people. And in such circumstances, the search for effective approaches to teaching foreign languages aimed at solving specific professional problems has become relevant.

According to the concept of modernization of education, the main aim of professional education in higher education is to train a qualified specialist of the appropriate level and profile, competitive, competent, and capable of effective work at the level of world standards, ready for continuous professional growth, social and professional mobility. The main strategic aim of teaching foreign languages will be the formation of a specialist ready for professional intercultural communication. In this regard, it is necessary to update the methods and approaches to training.

Under the approach to teaching foreign languages (I.L. Bim, M.N. Vyatyutnev, I.A. Zimnyaya, M.V. Lyakhovitsky, E.G. Azimov, A.N. Shchukin, M. K Kolkova, I.L. Kolesnikova, O.A. Dolgina, etc.), is understood the basic category of the methodology, which determines the theoretical strategy of teaching a language and the choice of teaching technology that implements such a strategy. That is, the approach to teaching is the implementation of the leading, dominant idea learning in practice in the form of a certain strategy and with the help of one or another teaching method. In a broad sense, the approach acts as the most general methodological basis for research and teaching in a specific area of knowledge, as a methodological basis for the development of methods-directions and, consequently, methods-models of teaching foreign languages.

The aim and objectives of the study

The aim of the article is to analyze and classify modern approaches in teaching a foreign language.

The above aim allows formulating the objectives of the research:

${ }^{*}$ Corresponding author's e-mail: Rakhmetova_Shnar@mail.ru 
- to study the theoretical and methodological base of modern approaches in teaching a foreign language;

- summarize the scientific data on this issue in the article.

\section{Literature review}

To solve the set objectives, the works describing the structures of higher education, the need for modernization of the higher education system under the principles of the Bologna Declaration [2] are considered. Researches on educational technology use for teaching and learning in high school are studied [3]. A review of modern sources in the implementation of the reform of the educational standard focused on competency and competency-based approach in teaching a foreign language has been carried out [4]. It also analyzes the main theses of the modern methodology of teaching a foreign language, particularly modern approaches in teaching a foreign language [5].

\section{Methods}

The research methodology of modern approaches in teaching a foreign language is based on a theoretical analysis of scientific literature, data synthesis, pedagogical observation, practical teaching a foreign language.

\section{Results and Discussion}

The approach to teaching is the basic category in the methodology giving an idea of the language researcher/teacher's views. It is the view both on the language itself and on how to master it. It is a component of the language teaching system, acts as the most general lingua didactic basis for mastering the language, and gives an idea of the chosen knowledge strategy, which serves as the basis for the choice of teaching methods and techniques.

The approach to teaching is the realization of the leading, dominant idea of learning in practice in the form of a specific strategy and using one or another teaching method. The approach to teaching is based on:

a) the corresponding theory of language (linguistic foundations of teaching);

b) the theory of teaching and learning (didactic foundations of teaching).

The term «approach to learning» was introduced in 1963 by the scientific methodologist E. Anthony to designate the starting points that «the researcher uses regarding the nature of the language and how to master it». To optimize the process of learning English, that is, to improve it as much as possible, various approaches are used [6].

Up to date, there is no single classification of approaches to teaching. There are many different approaches to teaching a foreign language from different points of view.

M.V. Lyakhovitsky identifies four approaches to teaching a foreign language from the perspective of psychology:

- behavioral - mastering the language through the formation of speech automatisms in response to the presented impetus;

- inductive-conscious - mastering the language as a result of observation of speech patterns, which leads to the mastering the language rules and methods of their use in speech;

- cognitive - conscious mastering the language in a sequence from knowledge in the form of rules and instructions to speech skills and abilities based on acquired knowledge;

- integrated - an organic compound in the classroom of conscious and subconscious components in the learning process, which is manifested in the parallel mastering knowledge and speech skills and abilities [7].

Currently, the schools use the model of developing the education of L. Vygotsky. The concept of this training includes new approaches:

- differentiated;

- competency-based;

- research;

- humanistic;

- problematic;

- developing;

- activity-based;

- communicative and others. 
Let's consider some approaches to teaching a foreign language from the above list.

The differentiated approach. One of the urgent problems of teaching foreign languages at school is a differentiated approach to teaching. Of course, for every teacher working in the school, this, at first glance, seemingly not a simple problem causes difficulties. The main difficulty is caused by the inability to find the optimal combination of individual, group, and whole-class work in teaching a foreign language. Other difficulties are associated with the determination of the individual characteristics of the student's personality and the teacher activity organization aimed at developing the mental abilities of each student.

A differentiated approach to teaching English is a multilevel approach. Differentiated training provides for such organizational forms in which each student works at the level of his/her abilities, overcoming an adequate, but significant difficulty for him/her [8].

The competency-based approach. One of the promising approaches to solving the problems posed to the modern education system is the competency-based approach [9].

The competency-based approach that embodies the innovative process in education today corresponds to the general concept of the educational standard adopted in most developed countries and is directly related to the transition to a system of competencies in the design of educational content and quality control systems. Also the relevance of the competency-based approach, regardless of specific representations and interpretations, is immersed in a special cultural and educational context, given the following trends in national education [10].

The main aim of teaching a foreign language at a university as part of a competency-based approach is to teach a foreign language as a real means of communication between specialists from different countries and simultaneously between representatives of different linguistic and cultural communities.

The fundamental difference between the concept of a competency-based approach in education and the previously existing subject-oriented concept consists in an attempt to realize the personal orientation of education, its activity-practical and cultural component, using standard methods, while preserving traditional fundamentality and universality.

The research approach to teaching is aimed at developing students' skills and scientific search skills, at the formation and development of creative abilities (creativity). Research training is a special approach to teaching based on a person's natural desire for an independent study of the world. In research teaching, the educational process is carried out based on an independent search of new cognitive orienting points by students. This allows ensuring that learning involves not only the assimilation of new information but also the organization of students' creative activities. In psychological terms, a student's educational and cognitive activity under certain conditions goes up to the research activity of a scientist. The difference is that the student in the learning process acquires knowledge that is new subjectively (for him/her), and the scientist obtains new knowledge through research in the relevant field of science (for society) [11].

Organizational ways to use the research approach in teaching English include individualization of education, students' free choice of additional educational services, the maximum variety of opportunities, sources of information, special attention to the organization of intersubject communications in individual work with students, and the creation of conditions for creative cooperation.

The organization of research activities in a foreign language takes place both at different levels and in various forms and manifestations. As for the integration of educational and research activities of students, this problem is still under development. In pedagogy, these activities are most often considered separately. The task is to combine (integrate) educational and research activities, to determine the goals, content, and methods of organizing educational and research activities.

The humanistic approach to teaching a foreign language is based on the humanistic direction in psychology. This approach is based on the thoughts, feelings, and emotions of students in the learning process, as well as on cognitive processes that facilitate learning and provide knowledge of the world and selfknowledge [12].

The topicality of the problematic approach to teaching a foreign language is determined by the new target orientation of modern education. The use of the problematic approach is to offer students problematic situations to teach the student to solve a particular problem in the event of a collision with it both at the lessons of their native language and at the lessons of a foreign language [13].

The developing approach to teaching foreign languages, the development vector of which is set by personality-oriented and competency-based approaches, provides a process of continuous development of the student's personality. Being an active and competent subject, the student interacts with various speech partners in the conditions of their native and non-native cultures, accumulates social experience, and acquires the 
qualities necessary for socially adequate interaction to solve personal and socially significant tasks. A person's social development of using a foreign language is understood as a process of formation and improvement of socially valuable qualities of a person as they accumulate, integrate, and actively reproduce social experience within their own and non-native cultures, which provides the opportunity for effective activity in the social sphere [14].

Using the activity-based approach forms the students' motivation to learn a foreign language, creates a positive emotional background of the lesson. The methods of work can be varied: game forms of activity during the introduction and consolidation of new vocabulary, the use of toys, the intensification of speech activity using a variety of didactic and handout material, the creation of computer animation and slides, voiced in a foreign language.

Unlike other approaches, the activity-based approach sets the formation of various types of speech as a guideline. The focus of this approach is on the mechanisms that provide the process of formation and development of socio-cultural skills with their subsequent implementation in the process of communication, that is, the process of transmitting speech-expressive statements from one participant to another as a result of the primary communicative activity (speech production) and secondary communicative activity (speech perception).

In parallel with the development of activities, the student will be able to form his/her system of values, supported by society. From a passive consumer of knowledge, a student becomes an active subject of educational activity. The category of activity with this approach to learning is fundamental and semantic for the entire learning process [15].

The communicative approach is perfectly motivated: its task is to interest students in learning a foreign language using accumulating and expanding their knowledge and experience. Students should be prepared to use the language for real communication outside the classroom, for example, while visiting the country of the language being studied, while receiving foreign guests at home, during correspondence. At the same time, the term communicativeness does not come down only to the establishment of social contacts through speech; it is the personal acquaintance with the spiritual values of other cultures.

The learning process in the framework of the communicative approach is built on the model of communication. Following this model, teaching is as close to real as possible communication [16].

It is realized in modern pedagogical researches (Kunanbayeva S.S., Khutorskoy A.V., I. Unt and others):

The cognitive approach. Knowledge, as known, is the result of a cognitive process. And calling the cognitive approach one of the leading methodological approaches of the modern process of teaching a foreign language, the emphasis is on taking into account the laws of the cognitive process in mastering a foreign language and the characteristics of the mental (intellectual-emotional) activity of students.

Concerning teaching a foreign language, cognitivism means that the study of a linguistic phenomenon should be based on the mental processes and actions that underlie the understanding and use of this phenomenon in speech. This approach emphasizes the need to take into account the peculiarities of students' mastering of a particular linguistic phenomenon, and also draws attention to the students' ability to organize their learning activities consciously.

Thus, in teaching a foreign language, the cognitive approach is reduced to the problem of the optimal organization of students' cognitive actions, corresponding to a person's natural cognitive behavior. That is, linguistic information is subject to the same cognitive laws as any other information that, to be assimilated, must be, firstly, analyzed, and, secondly, accessible for use, «automated».

The individual approach to teaching is one of the urgent problems of teaching foreign languages. The term «individual approach» is understood as a system of didactic tools for organizing the educational process in a foreign language, which includes changing the form of the lesson, purpose, content, and process. An individual approach to teaching a foreign language is considered a complex pedagogical phenomenon that determines the effectiveness of teaching a foreign language and assumes an active role in the subject of educational activity. The main condition for the implementation of an individual approach is differentiation, which is expressed in assessing the student's initial language training, setting goals that are personally significant for him/her, developing independent work skills, and the ability to implement a systematic approach to mastering new knowledge [17].

The personality-oriented approach determines the direction of the teacher in the learning process when implementing his/her interaction with the student. The new paradigm of education is changing approaches to the education system, putting the learner in the center of attention as an active subject who acquires behav- 
ioral personal knowledge» in the learning process, which forms and develops his/her intellect. In other words, the focus is on a person who is recognized as independent and unique. A feature of the pedagogical personality-oriented approach is that it is aimed at creating favorable conditions for the full development of this personality.

A personality-oriented approach to teaching foreign languages affects learning technology. In particular, it uses almost no forms of conducting classes that are not characterized by communicativeness.

In the framework of a personality-oriented approach, the student becomes the main subject and participant in the educational process, since it is he/she who has a significant influence on it, has the opportunity to rebuild it. The teacher has a different role. He/she must coordinate the process of learning the language, determine the educational goal and trajectory, organize the appropriate work, and provide resources. Students, in turn, must acquire knowledge and also understand how the educational process is built, how it can be applied in real life, that is, how you can acquire the necessary skills yourself, without a teacher's help. In this regard, the teacher must develop the ability of students to independently search for information and its analysis. Under such conditions, it is possible to talk about the critical thinking and creative activity of students. Therefore, the teacher must collaborate with students. This will create more favorable conditions for their freedom and initiative.

The structural approach to teaching a foreign language is based on the theses of structural linguistics and behaviorism in psychology. Learning under this approach involves mastering some grammatical structures-patterns, which are arranged in a certain sequence depending on the difficulty of their assimilation.

The lexical approach is based on the priority position of vocabulary in learning since it reflects the content side of the language. This approach means mastering the vocabulary in all its diversity and compatibility, the main attention is paid to the formation of speech skills of word use. The lack of formation of these skills causes errors at the level of the usus.

The contribution of the proponents of the lexical approach to learning in the methodology lies in the fact that they pay special attention to the content side of the statement, to the meaning that is conveyed by one or another lexical unit. Grammar is not given due attention, which leads to a large number of errors and disrupts the communication process.

The integrated approach to learning is based on the interconnected formation of skills in all four types of speech activity — listening, speaking, reading, and writing.

The term «integrated approach» can be correlated with the concept of «the principle of interconnected teaching of all types of communication», it is widespread in the domestic methodology. According to this principle, various types of speech activity can act as a goal and learning tool.

The auditive approach is based on the thesis that teaching a foreign language should imitate the process of mastering children's native language. Following this, listening as a receptive type of speech activity is leading in the learning process, the formation of skills to understand oral speech should be ahead of the formation of productive oral and speech skills. Teaching should be based on the transfer of listening skills to other types of speech activity. The main attention should be paid to the meaning of the studied language material, and not its form [18].

In this article, we will consider in detail the individual approach to teaching a foreign language.

Before starting the description of our experiment, we would like to refer to the content of The concept of foreign language education of the Republic of Kazakhstan by S.S. Kunanbayeva.

We consider it appropriate to refer to this document since in this section we will highlight issues related to the formation of linguistic competency in the group of the specialty «Foreign language: two foreign languages». So, in the above-mentioned document, the issue of the formation of competency and the role of the foreign language in the development of education in the Republic of Kazakhstan as a whole sounds as follows:

«... The integration processes that have been intensively developing in the last decade, the growth of professional and academic exchanges, and the deepening of international cooperation have stimulated the progressive development of foreign language education. Under these conditions, a foreign language acquires the status of an effective tool for the formation of the intellectual potential of society, which at the present historical stage is becoming one of the main resources for the development of a new state».

«... The orientation of the educational system of the Republic of Kazakhstan to a competency-based approach in the content of education is expressed in the field of teaching foreign languages in the formation of intercultural competency as an indicator of the formation of a person's ability to effectively participate in foreign language communication at the intercultural level» $[1 ; 10]$. 
Linguistic competency is, first of all, the possession of the system of information about the target language according to its levels: phonemic, morphemic, lexical, syntactic. A student has language competency if he/she has an understanding of the system of the language being studied and can use this system in practice.

«Linguistic competency is a complex psychological system, which includes, in addition to the information about the language learned during special education, the speech experience accumulated in the daily use of the language and the sense of language formed on its basis». This definition of linguistic competency was proposed by Y.D. Bozhovich.

Competency includes a set of interrelated personality traits (knowledge, abilities, skills, methods of activity), set concerning a certain range of objects and processes and necessary for high-quality productive activity to them. Linguistic competence implies knowledge of the language itself, its structure and functioning, linguistic norms, including spelling and punctuation.

The specificity of the formation of linguistic competency based on an individual approach is to provide each student with the right to choose his educational route of learning and self-study, control, and selfcontrol, as well as his/her self-development, taking into account educational and personal needs. The use of an individual approach allows you to measure and correct the level of language proficiency at each stage of bachelor's studies, to track and evaluate the student's progress; promote the personalization of language education.

The individual approach to teaching students «Foreign language: two foreign languages» involves the implementation of the students' cognitive activities, taking into account their abilities, capabilities, and interests, encouraging them to realize their creative potential.

Observation and testing are the main methods of learning linguistic competency.

Observation is a specially organized direct perception and registration of the speech of native speakers. It can take place in the natural conditions of the learning process without external influence on the observed object. Observation directly reflects the phenomenon, makes it possible to discover specific facts, which are the basis for a comprehensive objective description, subsequent analysis, generalization, and interpretation. It allows you to catch internal patterns and connections, the development of linguistic phenomena. The observation is carried out according to a preliminary planned plan. Oral speech can be monitored, for example, the speech of TV presenters and television participants. For these purposes, TV programs are recorded and further decoded. Written speech, such as the speech of authors of newspaper and magazine publications, can also be monitored. The speech of representatives of the media is the most significant source for the analysis of linguistic competency since it is in it that language changes are detected, their dynamics is traced. In the course of observations, language errors are recorded, which are an indicator of the level of formation of linguistic competency.

The main advantage of the observation method is that the focus of the researcher is on the process of verbal communication in the real form in which it takes place in a specific communication situation.

Testing is the organization of the performance of specially prepared tasks by the subjects (tests, dictations, etc.) and further statistical processing of the results of these tests. These tasks are intended to test the proficiency of certain linguistic phenomena. The data obtained during testing reflect all the necessary aspects of the subject of research; lend themselves to systematization and quantitative processing. Also, testing, as opposed to observation, is a much more time-saving method of diagnosing the learning process. However, it is used, as a rule, only in educational institutions.

Besides, according to some foreign researchers, in testing situations, the testee controls his/her speech actions to a greater extent than in natural speech situations, and this can give a distorted picture of the real state of his/her communicative and linguistic competency.

The observation method seems to us the most suitable for the study of linguistic competency, since it is purposeful and applied and involves working with a large amount of material, that is, it provides more reliable data. Therefore, we used this method to identify linguistic competency.

Referring to the individual approach to teaching students of the specialty «Foreign language: two foreign languages», we have compiled a set of experimental tasks, which includes exercises on the most likely ways to form the linguistic competency of students of the specialty «Foreign language: two foreign languages».

Using the presented tasks, we experimented to identify ways to form linguistic competency through an individual approach to teaching a foreign language. The material for analysis was collected by performing experimental tasks among students of the specialty «Foreign language: two foreign languages».

The aim of this experiment was the formation and improvement of linguistic competency through the individual approach to teaching a foreign language. Analyzing the results obtained, we were guided by the following algorithm: 
- diagnostics of the initial level of linguistic competency;

- identification of the leading channel of perception for improving linguistic competency through S. Yefremtsev's test of (Methodology of the leading channel of perception);

- determining whether this method of improving linguistic competency is effective in this case;

- if yes, then to establish the advantages of this method, it is necessary to use the individual approach to teaching a foreign language.

According to the results of the performed tasks, we observe that the degree of fulfillment of listening tasks is lower than the degree of fulfillment of tasks for other types of speech activity.

In our opinion, this happens because tasks for all types of formation of language skills and speech skills, except for listening, are based on fixed information. Also, in the case of completing tasks on these types of formation of linguistic competency, students have the opportunity to use auxiliary means (dictionaries, additional literature, etc.).

In this regard, we believe that the methodology for identifying the leading channel of students' information perception before starting the tasks for the formation of linguistic competency contributes to the effective implementation of these tasks and the development of many important skills. In this case, the form of individualization, and in particular individual work, enhances the process of implementing this technique during the experiment. The individual form of training assumes that each student receives an assignment for independent fulfillment, specially selected for him/her by his/her training and educational capabilities.

It is advisable to carry out individual work at all stages of the lesson while solving various didactic problems; for the assimilation of new knowledge and their consolidation, for the formation and consolidation of skills and abilities, for generalization and repetition of the past, for control, for mastering research experience, etc.

The individual form of training provides for the student to complete his/her task independently of others; this form of work contributes to the development of a high level of student independence and allows him to show his abilities.

Why is it important to know how students perceive information?

- The mastery of many important skills depends on which channel of perception the student has. For example, reading or writing.

- At a lesson, the teacher can present information to students using all channels of perception: vision, hearing, and kinesthetic channel. Then each of them has a chance to assimilate at least part of these messages. This usually happens. This chance is greatly enhanced if, for example, both the teacher and students are visuals (or audials).

- The features of mental work differ significantly, for example, the level of distraction, the peculiarities of memorization, etc.

If the teacher knows what category the student belongs to, it is easier for him/her to build a relationship with the students. Much becomes clear: why there are problems with discipline, why we "speak different languages», how to properly encourage the student or make him/her a remark.

We believe that knowledge of such characteristics of students helps to a greater extent to carry out differentiated teaching, the development of pedagogical techniques and methods following their psychophysiological characteristics.

In this regard, the students of the specialty «Foreign language: two foreign languages» were offered S. Yefremtsev's test «Methodology is the leading channel of information perception».

According to the test results, it was found that in the group, students have a kinesthetic channel of perception and a visual one.

Therefore, we have proposed some tasks, compiled taking into account the students' leading channel of perception.

The individual form of training provides for the student to complete his/ her task independently of others; this form of work contributes to the development of a high level of student independence and allows $\mathrm{him} / \mathrm{her}$ to show his/her abilities. This form of work can be attributed to work with handouts when a student receives an individual task, and the teacher checks its implementation, as well as the preparation and presentation of an essay on a given topic in a foreign language.

We also developed a set of exercises to confirm the hypothesis that taking into account the leading channel of information perception in the formation of language competence contributes to the effective implementation of these tasks and the development of many important skills. The language content of the exer- 
cises is taken from the educational and methodological complex of the discipline «Working with newspaper and magazine vocabulary», and the target set for them is developed following the leading channel of perception of information by students of specialty «Foreign language: two foreign languages» in the formation of linguistic competency through individualization learning.

In the process of directly preparing the analysis of the article, we clarified the topic «Newspapers in my life». The analysis of the article had to be presented in the form of a presentation.

When evaluating the student's oral answer, such criteria were taken into account:

- to be able to read and thoroughly understand the text of the article (with a dictionary);

- to give a clear definition of linguistic phenomena;

- to recognize lexical, grammatical, and syntactic structures;

- to explain the realities encountered in the text;

- to be able to retell and analyze the plot of the text in English;

- to be able to recognize stylistic devices, to isolate implicit content;

- to analyze the text taking into account the historical and cultural context.

The level of implementation of the formation of linguistic competency was assessed according to the following criteria, which have a qualitative aspect:

A low level - there is no accuracy in written speech. The student's analysis does not show consistency, clarity, linguistic correctness, expressiveness of speech. Also, in his/her speech, the student uses simple, not complex sentences. There are $2-3$ errors in the plot sequence.

An average level - in the student's speech there is communicative expediency, clarity, but there is no content, consistency. There are 1-2 errors in the plot sequence. There are attempts to convey view of the described subject of speech, but these attempts are few in number and episodic.

A high level - meaningfulness is traced in the student's speech, the student builds his/her sentences in his/her speech consistently, logically, accurately, and also uses expressive words, phrases in his/her speech, answering questions expediently and clearly. The picture plot is assembled correctly and consistently. The author's perception of the subject of speech is conveyed.

The levels of formation of linguistic competency through an individual approach to teaching a foreign language to students of specialty «Foreign language: two foreign languages» are reflected in Table 1.

T a ble 1

\begin{tabular}{|c|c|c|}
\hline Levels of formation of linguistic competency & Number of students in the group & Percentage \\
\hline high & 6 & $46 \%$ \\
\hline average & 5 & $39 \%$ \\
\hline low & 2 & $15 \%$ \\
\hline Total & 13 & $100 \%$ \\
\hline
\end{tabular}

The high level of formation of linguistic competency through individualization in a group characterizes $46 \%$ of students, the average level $-39 \%$ of students, the low level $-15 \%$.

As a result of our experiment, we can conclude that the effectiveness of our set of exercises had been proven. The formation of linguistic competency in teaching a foreign language is effective when taking into account the individual approach of teaching students. That is, reliance the an individual approach in teaching a foreign language influenced the quality of education.

The analysis of the existing methods of teaching a foreign language made it possible to explain of why none of them is universal for all students and always assumes some psychological types of students for whom it does not suit.

Analysis of the psychological characteristics of trainees, which were named by various methodologists as important for the success of learning (including various types of memory, motivation, volitional qualities, features of the nervous system, etc.), as well as consideration of the entire spectrum of cognitive and other styles identified by various researchers, made it possible to conclude that it is the leading channels of information perception that are responsible for the success of the processes of perception, processing, memorization, and use of linguistic information.

The students' professional knowledge, skills, and abilities formed at the end of the course help to speak and judge about successful learning and the effectiveness of individual work. Relevant and necessary in a multilingual environment: the abilities to analyze and solve situations in the professional sphere outside the 
box, work with professional literature in foreign, Russian, Kazakh languages, navigate and integrate into a foreign language environment, knowing its nature and characteristics.

The results of the study show that the formation of linguistic competency through the individual approach to teaching a foreign language can be achieved by expanding the range of tasks focused on students' psycho-cognitive types.

\section{Conclusions}

To implement modern social requirements, new approaches are being developed. So the use of personality-oriented, competency-based, communicative, differentiated, integrated, lexical, cognitive, and other teaching approaches enables teachers to find an individual approach to each student. These approaches help in organizing the learning process to pay attention to each student individually and at the same time work with the whole group at the same time. The ultimate goal of each of these approaches is to develop in students the ability to independently acquire knowledge and solve problems.

A lesson, as the main form of organization of the teaching process, allows the teacher to put into practice modern approaches. Each of these approaches requires special preparation, both on the part of the teacher and students. Of course, success depends on many factors - on the teacher's knowledge of the subject and general erudition, in other words, on the teacher's personality. But this is not enough - you also need knowledge of methodological skills, moreover, it is necessary for a teacher of a foreign language.

In the conclusion, it should be noted that in practice it is necessary to combine different approaches and use those that are most effective in a particular situation.

Based on the abovementioned, we can summarize that each approach is very important in the lesson planning system today; each teacher must adhere to one or another approach, but the approaches cannot be used simultaneously, so you need to have a fine feel for each student before choosing the core of their professional activity. Also, the teacher must take into account that the effectiveness of a particular methodology within the framework of a particular approach to teaching depends on its relevance to the stated problem, the teacher's ability to regulate the time of using this approach, and the quality of the organization of preliminary training, which requires careful study of issues for discussion, development of students' skills and communicative abilities.

\section{References}

1 Кунанбаева С.С. Концепция иноязычного образования Республики Казахстан / С.С. Кунанбаева. - Алматы: Казах. ун-т междунар. отн. и мир. яз. им. Абылай хана, 2010. - 20 с.

2 Maassen P. The knowledge triangle, European higher education policy logics and policy implications / P. Maassen, B. Stensaker // Higher Education. — 2010. - Vol. 61, 757-769. DOI 10.1007/s10734-010-9360-4.

3 Hollands F. How research informs educational technology decision-making in higher education: the role of external research versus internal research / F. Hollands, M. Escueta // Educational Technology Research and Development. — 2020. — Vol. 68, Issue 1, 163-180. — ISSN: 1042-1629. https://doi.org/10.1007/s11423-019-09678-z.

4 Zuber J. The role of teacher characteristics in an educational standards reform / J. Zuber, H.Altrichter // Educational Assessment, Evaluation, and Accountability. — 2018. — Vol. 30, Issue 2, 183-205. — ISSN: 1874-8597. https://doi.org/10.1007/s11092018-9275-7.

5 Larsen-Freeman D. / Teaching and Principles in Language Teaching. / D. Larsen-Freeman, R.N. Campbell, W.E. Rutherford. - New York, 2008. - $191 \mathrm{p}$.

6 Larsen-Freeman D. Teaching and Principles in Language Teaching / D. Larsen-Freeman, M. Anderson. Third Edition. New York, 2016. - 318 p.

7 Ляховицкий М.В. Методика преподавания иностранных языков / М.В. Ляховицкий. — М.: Высш. шк., 1981. - 159 с.

8 Унт И.Э. Индивидуализация и дифференциация обучения / И.Э. Унт. - М.: Педагогика, 1990. — 192 с.

9 Хуторской А.В. Компетентностный подход в обучении: науч.-метод. пос. / А.В. Хуторской. — М.: Изд-во «Эйдос», 2013. - $73 \mathrm{c}$.

10 Кунанбаева С.С. Компетентностное моделирование профессионального иноязычного образования: моногр. / С.С. Кунанбаева. - Алматы, 2014. - 208 с.

11 Шарипов Ф.В. Исследовательский подход к образовательному процессу / Ф.В. Шарипов // Научное обозрение. Педагогические науки. — 2016. - № 6. - С. 150-154.

12 Колкова М.К. Традиции и инновации в методике обучения иностранным языкам / М. К. Колкова. - СПб.: КАРО, 2007. - 288 c.

13 Поталуй В.В. Проблемное обучение при изучении иностранных языков: эффективность и трудности / В.В. Поталуй, Е.А. Ширшикова // Филологические науки. — 2015. — № 6. - С. 75-77. 
14 Ариян М.А. Социально-развивающая методическая система обучения иностранным языкам в средней школе: проектирование и реализация: автореф. дис. ... д-ра пед. наук: спец. 13.00.02 - «Теория и методика обучения и воспитания (иностранные языки, уровень высшего профессионального образования)» / М.А. Ариян. — Нижний Новгород, $2009 .-45$ с.

15 Гальскова Н.Д. Теория обучения иностранным языкам. Лингводидактика и методика: учеб. пос. / Н.Д. Гальскова, Н.И. Гез. - М.: Изд. центр «Академия», 2006. - 336 с.

16 Хуторской А. Ключевые компетенции. Технология конструирования / А. Хуторской // Народное образование. 2003. - № 5. - C. 55-61.

17 Пассов Е. И. Урок иностранного языка / Е.И. Пассов, Н.Е. Кузовлева. — Ростов н/Д.: Феникс; М.: Глосса-Пресс, 2010. $-610 \mathrm{c}$.

18 Кашина Е.Г. Традиции и инновации в методике преподавания иностранного языка: учеб. пос. для студ. филол. фак. ун-тов / Е.Г. Кашина. — Самара: Изд-во «Универс-групп», 2006. — 75 с.

\title{
Ш.С. Рахметова
}

\section{Шетел тілін оқытудағы заманауи тәсілдер}

\begin{abstract}
Мақалада шет тілін оқытудағы заманауи тәсілдердің классификациясы қарастырылған. Бір немесе бірнеше шет тілдерін білу көптеген адамдар үшін өзекті мәселеге айналды. Осындай жағдайларда нақты кәсіби мәселелерді шешуге бағытталған шет тілдерін оқытудың тиімді тәсілдерін іздеу шынымен өзекті бола бастады. Мақаланың мақсаты - шет тілін оқытуда заманауи тәсілдерді талдау және жіктеу. Жоғарыда келтірілген мақсат зерттеу міндеттерін анықтауға мүмкіндік береді: шет тілін оқытудағы заманауи тәсілдердің теориялық және әдістемелік негізін зерттеу; осы мәселе бойынша ғылыми деректерді жинақтау. Қойылған міндеттерді шешу үшін жұмыста жоғары білім құрылымдары, жоғары білім жүйесін Болон декларациясының қағидаларына сәйкес модернизациялау қажеттілігі сипатталған. Жоғары оқу орындарында оқыту үшін білім беру технологияларын қолдану мәселелері зерттелді. Шет тілін оқытуда құзыреттілік пен құзыреттілікке негізделген білім беру стандартын реформалауды жүзеге асыруда қазіргі заманғы дереккөздерге шолу жасалды. Онда сонымен қатар қазіргі шет тілін оқыту әдістемесінің негізгі ережелері, атап айтқанда шет тілін оқытудағы заманауи тәсілдер талданған.
\end{abstract}

Кілт сөздер: заманауи тәсілдер, шет тілі, білім беру жүйесі, оқыту, оқыту әдістері, жоғары білім, оқу процесі, құрылым.

\section{Ш.С. Рахметова}

\section{Современные подходы при обучении иностранному языку}

В статье рассмотрена классификация современных подходов при обучении иностранному языку. Знание одного или нескольких иностранных языков стало актуальной проблемой для многих людей. И в таких условиях поиск эффективных подходов обучения иностранным языкам, направленных на решение конкретных профессиональных задач, стал действительно актуальным. Цель статьи - проанализировать и классифицировать современные подходы при обучении иностранному языку. Названная выше цель позволяет сформулировать задачи исследования: изучить теоретико-методологическую базу данных подходов; обобщить научные данные по данному вопросу. Для решения поставленных задач рассмотрены работы, описывающие структуры высшего образования, необходимость осуществления модернизации системы высшего образования в соответствии с принципами Болонской декларации. Изучены исследования использования образовательных технологий для обучения в высшей школе. Проведен обзор современных источников в области реализации реформы образовательного стандарта, ориентированного на компетенцию и компетентностный подход при обучении иностранному языку. Кроме того, проанализированы основные положения методики преподавания иностранного языка, в частности, актуальные подходы.

Ключевые слова: современные подходы, иностранный язык, система образования, обучение, методика преподавания, высшее образование, учебный процесс, структура.

\section{References}

1 Kunanbaeva, S.S. (2010). Kontseptsiia inoiazychnoho obrazovaniia Respubliki Kazakhstan [The concept of foreign language education of the Republic of Kazakhstan]. Almaty: Kazahskii universitet mezhdunarodnykh otnoshenii i mirovykh yazykov imeni Abylai khana [in Russian].

2 Peter Maassen \& Bjørn Stensaker. (2010). The knowledge triangle, European higher education policy logics and policy implications//Higher Education. Vol. 61, 757-769. DOI 10.1007/s10734-010-9360-4. 
3 Fiona Hollands \& Maya Escueta. (2020). How research informs educational technology decision-making in higher education: the role of external research versus internal research//Educational Technology Research and Development . - Vol. 68, Issue 1, 163180. — ISSN: 1042-1629. https://doi.org/10.1007/s11423-019-09678-z

4 Julia Zuber \& Herbert Altrichter. (2018). The role of teacher characteristics in an educational standards reform// Educational Assessment, Evaluation and Accountability. Vol. 30, Issue 2, 183-205. — ISSN: 1874-8597. https://doi.org/10.1007/s11092-0189275-7

5 Diane Larsen-Freeman, Russell N. Campbell \& William E. Rutherford. (2008). Teaching and Principles in Language Teaching. New York.

6 Diane Larsen-Freeman \& Marti Anderson. (2016). Teaching and Principles in Language Teaching. Third Edition. New York.

7 Liakhovitskii, M.V. (1981). Metodika prepodavaniia inostrannykh yazykov [Methods of teaching foreign languages]. Moscow: Vysshaia shkola [in Russian].

8 Unt, I.Je. (1990). Individualizatsiia i differentsiatsiia obucheniia [Individualization and differentiation of education]. Moscow: Pedahohika [in Russian].

9 Khutorskoi, A.V. (2013). Kompetentnostnyi podkhod v obuchenii. Nauchno-metodicheskoe posobie [Competency-based approach to learning. Scientific and methodological manual]. Moscow: Izdatelstvo «Eidos» [in Russian].

10 Kunanbaeva, S.S. (2014). Kompetentnostnoe modelirovanie professionalnoho inoiazychnoho obrazovaniia: monohrafiia [Competence modeling of professional foreign language education: monograph]. Almaty [in Russian].

11 Sharipov, F.V. (2016). Issledovatelskii podkhod k obrazovatelnomu protsessu [The research approach to the educational process]. Nauchnoe obozrenie. Pedahohicheskie nauki. — Scientific Review. Pedagogical sciences. № 6, 150-154 [in Russian].

12 Kolkova, M. K. (2007). Traditsii i innovatsii v metodike obucheniia inostrannym yazykam [Traditions and innovations in the methodology of teaching foreign languages]. Saint Petersburg: KARO [in Russian].

13 Potalui, V.V. \& Shirshikova, E.A. (2015). Problemnoe obuchenie pri izuchenii inostrannykh yazykov: effektivnost i trudnosti [Problematic education in the study of foreign languages: efficiency and difficulties]. Filolohicheskie nauki — Philological Sciences, № 6, 75-77 [in Russian].

14 Ariian, M.A. (2009). Sotsialno-razvivaiushchaia metodicheskaia sistema obucheniia inostrannym yazykam v srednei shkole: proektirovanie i realizatsiia [Socially developing methodological system of teaching foreign languages in high school: design and implementation]. Doctor's thesis. Nizhnii Novhorod [in Russian].

15 Galskova, N.D. \& Gez, N.I. (2006). Teoriia obucheniia inostrannym yazykam. Linhvodidaktika i metodika [Theory of teaching foreign languages. Linguodidactics and methods]. Moscow: Izdatelskii tsentr «Akademiia» [in Russian].

16 Khutorskoi, A. (2003). Kliuchevye kompetentsii. Tekhnolohiia konstruirovaniia [Key competencies. Construction Technology]. Narodnoe obrazovanie - Public Education, 5, 55-61 [in Russian].

17 Passov, E.I. \& Kuzovleva, N.E. (2010). Urok inostrannoho yazyka [A foreign language lesson]. Rostov na/Donu: Feniks; Moscow: Hlossa-Press [in Russian].

18 Kashina, E.G. (2006). Traditsii i innovatsii v metodike prepodavaniia inostrannoho yazyka: uchebnoe posobie dlia studentov filolohicheskikh fakultetov universitetov [Traditions and innovations in the methodology of teaching a foreign language: a textbook for students of philological faculties of universities] Samara: Izdatelstvo «Univers-hrupp» [in Russian]. 